\title{
Landscape heterogeneity and long-term animal production in Tierra del Fuego
}

\author{
ANA M. CINGOLANI, JUAN ANCHORENA, AND MARTA B. COLLANTES
}

Authors are range ecologists, Centro de Ecofisiología Vegetal (CEVEG-CONICET), Serrano 6696 to piso. 1414 Buenos Aires. Argentina.

\section{Abstract}

Grasslands of northern Tierra del Fuego sustain 1 sheep/ha and are very extensively managed, with flocks roaming freely in large paddocks (2,000-4,000 ha). This system requires knoweledge of landscape-level constraints and influences upon production for decision making. On a typical sheep ranch we checked upland floristic gradients against 30-years records of animal production. Community types and landscape units were surveyed and mapped. Using gradient analysis techniques we obtained animal production differences at the landscape scale that were strongly related to a vegetation gradient associated with soil fertility. Extensive and strongly variable lithological mantles allowed expression of the fertility gradient at that scale. Landscapes with fertile soils and neutrophilous community types were best for sheep breeding. These landscapes produced a mean of $37 \%$ more lambs ha ${ }^{-1} \mathrm{yr}^{-1}$ than lands with soils of intermediate fertility and slighty acidophilous community types, and $116 \%$ more lambs $\mathrm{ha}^{-1} \mathrm{yr}^{-1}$ than lands with highly infertile soils and highly acidophilous vegetation. Contrarily, the soil moisture gradient, being mainly expressed at the topographic scale, was not related with sheep production records. A forage gradient which was identified behind the fertility gradient supported our findings. Poa spp., the main item in sheep diets, and other important forage species attained the highest covers in neutrophilous cammunity types. With the range in proportion of lowlands present in this ranch (12 to $30 \%)$, no relationship was found between the percentage of hygrophitic vegetation in the landscape and animal production.

Key Words: floristic gradient; fertility gradient; grassland; parent material; sheep breeding performance; sheep production

Large herbivores are strongly influenced by heterogeneity at the landscape scale (McNaughton 1985, Senft et al. 1987, McNaughton et al. 1988), probably because of their high mobility

We are grateful to María Behety owners and staff, especially to chief administrator Patricio Suárez and his wife Karen for their kind hospitality and the supplying of useful information for this work. Field survey was possible thanks to the vehicle supplied by Enrique Livraghi of INTA. We also thank Marcela Cueto for her helping with animal husbandry information and terminology; and to Joaquín Muiller, Rodolfo Golluscio and Daniel Ginzo for critical comments on the manuscript. Daniel Ginzo and Susana Stofella read critically the English version. This research was financially supported, in part, by the Consejo Nacional de Investigaciones Científicas y Técnicas. (CONICET PID № 308550088)

Manuscript accepted 16 Mar. 1997.

\section{Resumen}

Los pastizales del norte de Tierra del Fuego sustentan una carga de 1 ovino/ha y se hallan bajo un sistema de manejo muy extensivo, con cuadros alambrados de 2,000 a 4,000 ha. Este sistema requiere conocimientos de las restricciones e influencias sobre la producción a escala de paisaje para la toma de decisiones. En un establecimiento típico hemos comparado los gradientes de vegetación climática (campos altos) con registros de $\mathbf{3 0}$ años de manejo y producción animal. Se relevaron y mapearon tipos de vegetación y unidades de paisaje. Utilizando técnicas de análisis de gradientes se obtuvieron diferencias en la producción animal a escala de paisaje que estuvieron fuertemente relacionadas con un gradiente de vegetación asociado a la fertilidad del suelo. Mantos litológicos extensos y variables permiten la expresión del gradiente de fertilidad a dicha escala. Los paisajes con suelos fértiles y comunidades neutrófilas fueon los mejores para la cría de ovinos. Estos paisajes produjeron en promedio un 37 \% más corderos $\mathrm{ha}^{-1}$ año ${ }^{-1}$ que los campos con suelos de fertilidad intermedia y comunidades vegetales levemente acidófilas, y un $116 \%$ más corderos ha $\mathrm{añ}^{-1}$ que los campos con suelos muy infértiles y vegetación altamente acidófila. El gradiente de humedad del suelo, que está expresado principalmente a eccala topográfica, no estuvo relacionado con la producción oving registrada por cuadro alambrado. Los resultados fueron apoyados por un gradiente forrajero que se encontró asociado al gradiente de fertilidad. Poa spp., principal constituyente de la dieta ovina, $\mathbf{y}$ otras especies forrajeras importantes alcanzaron las mayores coberturas en las comunidades neutrófilas. Dentro del rango de proporción de valles presente en este establecimiento (12 al $30 \%$ ), no se encontró ninguna relación entre el porcentaje de vegetación higrofitica en el paisaje y la producción animal.

(Pearson et al. 1995). Since manipulation of the environment at the landscape scale is difficult (Turner et al. 1989), knowledge of landscape influences on animal production is of basic importance for management of extensive grazing systems. In northern Tierra del Fuego (Argentina) the principal land-use is the extensive breeding of Corriedale sheep on 30,000 to 70,000 ha ranches where animals roam freely year round in paddocks sized 2,000 to 4,000 ha. The main management constraint is the severe shortage of winter forage which results in part from limited access to the lowlands, flooded in that season (Anchorena and Collantes 1989).

Upland vegetation can be described on a regional scale in terms of soil-fertility and moisture gradients. Soil fertility is strongly 
associated with geomorphology and determined by the chemical composition of the parent material (Collantes et al. 1989). The geomorphic control determines the influence of fertility at the landscape scale. Observation of contrasting sheep diets at this scale (Posse et al. 1996) encouraged a closer analysis of animal productivity along regional gradients.

We used annual records of management and production of individual paddocks taken along a 30 -year period in a representative ranch of the region. Our objective was to relate this production information to environment and vegetation. The following specific questions guided our work: 1) How well are the regional vegetation gradients and associated landscape types represented on the ranch?; 2) How do moisture and fertility gradients relate to forage value?; 3) Are those gradients associated with animal productivity?; and 4) Have the proportion of hygrophitic vegetation in the landscape any relationship with productivity?

\section{Materials and Methods}

\section{Study Area}

The study was carried out on the María Behety ranch $(60,000$ ha), located near Río Grande city $\left(53^{\circ} 47^{\prime} \mathrm{S}, 67^{\circ} 42^{\prime} \mathrm{W}\right)$, Tierra del Fuego province. It is at the center of the insular sector of the Magellanic steppe (Hueck and Seibert 1972) which is a more humid variant of the Patagonian steppe (Cabrera 1971). Altitude of the ranch is between 20 and $130 \mathrm{~m}$ a.s.l. with mean annual rainfall of $350 \mathrm{~mm}$, and evenly distributed throughout the year. However, a high water deficit occurs in summer (Koremblit and Forte-Lay 1991) due to high potential evaporation rates caused mainly by strong winds (Walter and Box 1983). The island climate, cloudy, cold and windy, with mean temperatures of $10^{\circ} \mathrm{C}$ in summer and $0^{\circ} \mathrm{C}$ in winter when snow is common (Fuerza Aérea Argentina 1986), is hostile for both man and animals.

Geology and geomorphology of the area have been described by Codignotto and Malumian (1981) and Frederiksen (1988) as part of regional studies. Miocenic sediments form a landscape of plains, asymmetric hills ("cuestas") and depressions ("playas") in the northern sector of the ranch. Glacial and fluvioglacial deposits from the Pleistocene cover an extensive area with terraced systems and moraines. In several places the glacial till is only a thin cover on top of subsisting Tertiary morphology.

The upland vegetation consists of 3 main physiognomic types: the Festuca gracillima (Hooker f.) tussock grassland, the Chiliotrichum diffusum ((Forster f.) O. Kunze) scrub, and the Empetrum rubrum (Vahl ex Willd) heathland ${ }^{1}$. Lowlands are dominated by meadows and marshes which occupy up to $30 \%$ of the landscape area.

Although stocking rate on the island is one of the highest for Argentinean Patagonia (about 1 sheep/ha), land use has remained very extensive since colonization (Belza 1975). The María Behety ranch has been subdivided into 27 main paddocks sized 2,000 to 4,000 ha each for at least 40 years. Fencing decisions were guided to allow grazing of particular types of land with particular kinds of animals. Empetrum heathlands, considered the poorest lands, have been grazed with low nutritive requirement animals such as wethers. Corridors or islands of meadows and marshes, the best summer lands, and their associated watering

Tpecies nomenclature follows Correa (1969-1984) unless otherwise stated. points were included in similar proportions (around $20 \%$ ) in all ewe paddocks. Tussock grasslands and Chiliotrichum scrubs, the most extensive vegetation types, dominate the ewe paddocks, and secondary production depends largely on them.

After shearing and weaning, animals are allocated to different paddocks in February. In March and April final culling and sale is done. Mating begins in May, and 95\% of births occurs in October. In the last week of November lambs are counted and marked. Mustering and counting of sheep take place in November (lamb marking), June (eye shearing), and January (shearing). Ewes usually remain in the same paddock for their entire reproductive life after first service.

For each year and paddock, the following 30-year (1962-1992) records were obtained from the ranch administration: 1) number and type of animals (sheep and cattle) at the onset of the winter season (June); 2) number of ewes in November (date of lamb marking); and 3) percentage of lambs marked per ewe present at marking (marking percentage).

\section{Landscape and Vegetation Analysis}

Types of landscape, distinctive and repetitive patterns of geoforms, were described and mapped on aerial photos $(1: 40,000)$. This was accomplished with photo interpretation of stereo pairs and visual interpretation of a LANDSAT MSS satellital image and with the support of published (Codignotto and Malumian 1981, Frederiksen 1988) and unpublished data.

During the summer of 1992, 64 upland sites were sampled. Sites were selected and stratified by landscape analysis of aerial photos. At each site all phanerogamic species were recorded, and their cover was estimated with the Braun-Blanquet scale modified by Westhoff and van der Maarel (1978). Aspect, slope, and site geoform were recorded. Nearby outcrops or cuttings were used to determine type of rock. Samples (64) and species (97, omitting single appearances) were simultaneously classified with the TWINSPAN divisive method (Hill 1979) and ordinated with Detrended Correspondence Analysis (DECORANA, Hill and Gauch 1980). For both analyses, alphanumeric values of species cover-abundance were transformed into numeric values from 1 to 9 (van der Maarel 1979).

Field information on geomorphology was used to check the landscape types mapped on the photos. Association between the types of landscape described and community types obtained by TWINSPAN was analyzed visually by superimposing both types of data for each sample on the floristic ordination diagram. Community types were mapped at scale $1: 40,000$ by photo interpretation; topographic maps 1:100,000 (Instituto Geográfico Militar 1942) were used as planimetric support. Mapping was based on landscape-vegetation associations and on photographic patterns of the community types that were checked during traverse and sampling.

\section{Analysis of Forage and Sheep Production}

To test for the relationship between forage value and the floristic ordination, relevant taxa of winter sheep diet (Posse et al. 1996) were selected. Sample cover values of the grasses Festuca gracillima, Poa spp., Hordeum spp., Bromus spp., Agropyron fuegianum ((Speg.) F. Kurtz), and Deschampsia spp., and of the forb Cerastium arvense (L.) were correlated with the sample scores on the DECORANA ordination axes using the Spearman rank correlation test (Conover 1980). 
For each paddock, the following productivity indices were calculated from the figures provided by the ranch administration:

Winter stocking-rate: Number of animals per ha. The number of animals used were the June figures, recalculated as "ewe equivalents" (EE) (Buffoni and Paz 1982) in order to account for different animal categories. The area of lakes and non vegetated units was subtracted from the paddock area.

Marking percentage: Percentage of lambs marked per ewe present in November.

Winter mortality: Losses of ewes between June and November counts, expressed as percentage of the total number for June.

To relate the sheep productivity indices with vegetation floristic gradients, paddocks had to be located on the DECORANA ordination space. For this purpose we applied the following procedures: 1) centroids of each community type in the 2 first ordination axes of DECORANA were calculated by averaging the axes scores of the samples belonging to each community type; 2) total area and that of each community type, lakes and other units were measured for each paddock with a digital planimeter on the vegetation map; then, 3) the proportional area of each upland community type relative to total upland vegetation was used as a weighting factor of centroids values in a summatory of community scores to obtain paddock scores on the 2 axes:

$$
S i j=\sum_{k=1}^{6} p i k c j k
$$

where $\mathrm{Sij}$ is the score of paddock $\mathrm{i}$ in Axis $\mathrm{j}$; pik the proportion of community $k$ in paddock $i$; and $c j k$, the centroid of community $k$ in Axis $\mathrm{j}$.
The calculated sheep and land production indices were linearly regressed with the estimated scores of the paddocks in the 2 axes. For each index a single value by paddock was calculated by averaging the 30 years of data. All 27 paddocks were considered for stocking rate; but for marking percentage and ewe mortality, only the 17 paddocks used for breeding were considered. Some of these had $<30$ years of records because they were not always used with breeding ewes.

Types of landscape (Fig. 1) were placed on the axes in the same way as paddocks, according to their proportion of upland communities obtained from the vegetation map (see Table 1). This allowed estimates of mean sheep productivity to be calculated for each landscape type from the regression models. To estimate influence of hygrophitic vegetation on breeding, paddock productivity indices were linearly regressed on the proportion of paddock area mapped as meadows and marshes.

\section{Results}

\section{Maria Behety Landscape Types}

Eight landscape types were defined for the following 3 lithological groups: Tertiary, Quaternary and Mixed landscapes (Fig. 1). Fence lines drawn on the map of Fig. 1 show that in most cases a paddock was occupied by 1 or 2 landscape types.

Tertiary landscapes were never covered by Pleistocene glaciations. They occurred over tilted sediments of 3 types: shales, sandstones and marine conglomerates, in order of increasing degree of resistance to erosion, and formed a landscape of asymmetrical hills or cuestas. A thin sheet of silty loess frequently covered these sediments. Two types of landscape were defined: "Tertiary undulated plains" and "Tertiary hills".

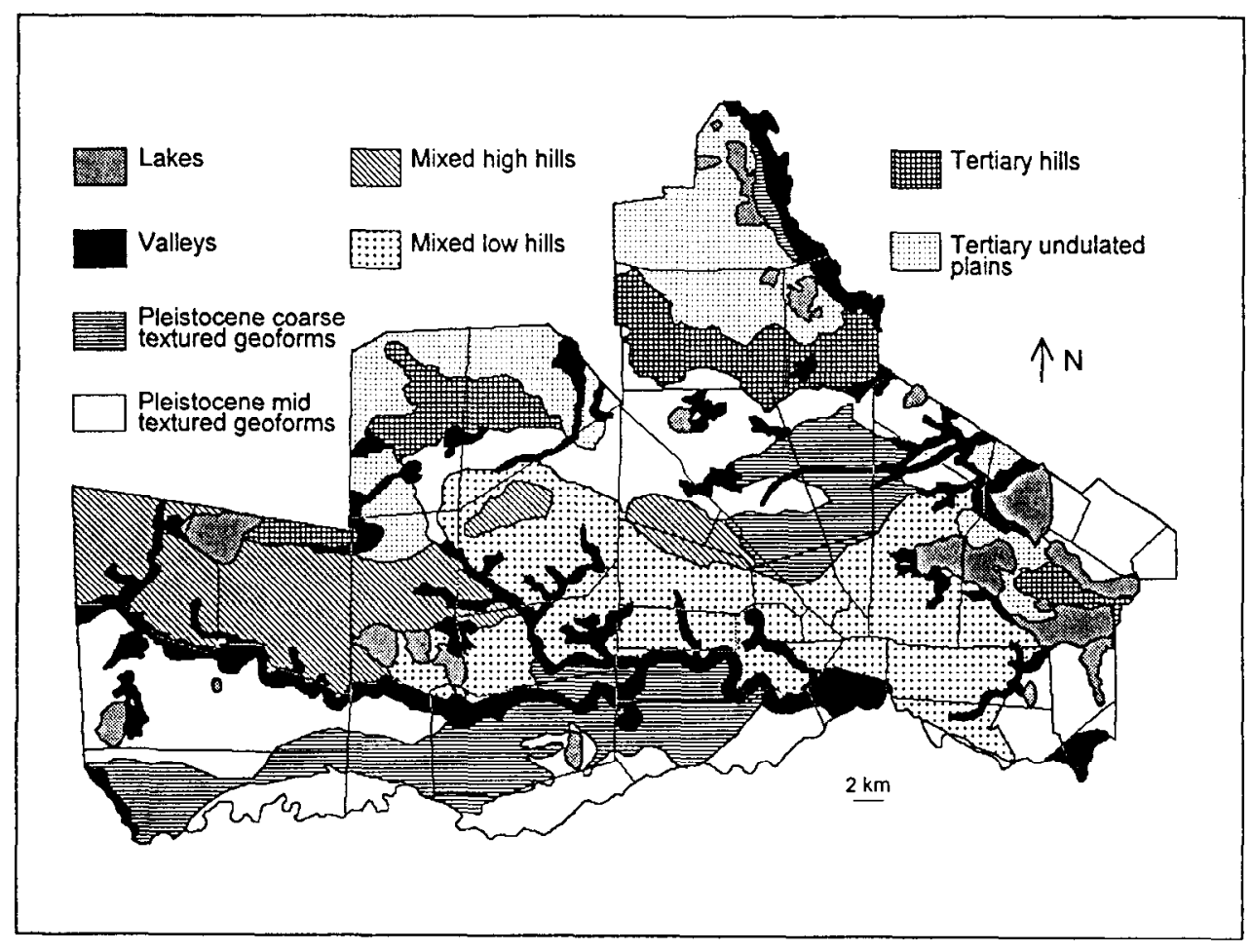

Fig. 1. Landscape types and paddocks on Maria Behety ranch. 
Table 1. Percent area occupied by each landscape type ${ }^{1}$ in the ranch $(63,032 \mathrm{ha})$ and proportion of community types ${ }^{2}$ in each landscape type. Lines enclosed main communities in each landscape.

\begin{tabular}{|c|c|c|c|c|c|c|c|c|c|c|}
\hline \multicolumn{5}{|c|}{ Landscape } & \multicolumn{5}{|c|}{ Community types ${ }^{2}$} & \multirow[b]{3}{*}{ Lakes } \\
\hline \multirow[b]{2}{*}{ Type } & & \multicolumn{3}{|c|}{-Neutrophilous types } & \multicolumn{3}{|c|}{ Acidophilous types } & \multicolumn{2}{|c|}{ Lowlands } & \\
\hline & $e^{1} \%$ area & 1 & 2 & 3 & 4 & 5 & 6 & 7 & 8 & \\
\hline & & & & & & & & & & \\
\hline A & 11.07 & 3. & & 6.8 & 1.8 & 2 & 0 & 20.4 & 1.6 & 0.0 \\
\hline $\mathbf{B}$ & 7.3 & 7.7 & 30.4 & 25.2 & 12.2 & 9.8 & 0. & 14.7 & 0.0 & 0.0 \\
\hline C & 17 & 4. & 5.5 & 12.8 & - & & & 23.3 & 0.0 & 0.0 \\
\hline $\mathrm{D}$ & & 7. & 1.1 & $\overline{0.0}$ & 44.9 & & 2 & 16.8 & 0.0 & 0.0 \\
\hline $\mathbf{E}$ & 23.59 & 2.0 & 3.2 & 1.0 & 18.2 & & 7.7 & 24.7 & 0.0 & 0.0 \\
\hline$F$ & & . & 0.0 & 0.0 & $\overline{8.1}$ & & 70.3 & 12.0 & 0.0 & 0.0 \\
\hline G & & 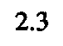 & 3.3 & 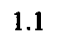 & 5.6 & & 3.3 & 70.5 & 2.2 & 0.0 \\
\hline $\mathrm{H}$ & 5.34 & 0.0 & 5.7 & 1.8 & 0.0 & 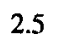 & 0.0 & 7.0 & 17.4 & 65.6 \\
\hline otal & $\mathrm{a}^{3} 100$ & 3.5 & 11.8 & 5.3 & 16.9 & 20.8 & 11.8 & 24.7 & 1.3 & 3.5 \\
\hline
\end{tabular}

Landscape types: A, Tertiary undulated plains; B, Tertiary hills: C, Mixed low hills; D, Mixed high hills; E, Pleistocene mid-textured geoforms; F, Pleistocene coarse-textured geoforms; G, Holocene valleys; $\mathrm{H}$, Holocene lakes.

'Community types: 1, Poa short grassland; 2, Festuca-Poa grassland; 3, Chiliotrichum dense scrub; 4, Chiliotrichum-Festuca shrubby grassland; 5, Festuca-Empetrum grassland; 6, Empetrum heathland; 7, meadows; 8 , halophytic marshes.

${ }^{3}$ Percent area occupied by each community type in the whole ranch area.

Quaternary landscapes were either Pleistocenic or Holocenic. Pleistocenic landscapes were fluvioglacial plains, moraines, and marine terraces formed on a gravelly substrate deposited over Tertiary sediments. The textural differences of deposits were considered to define 2 groups: "Pleistocene mid-textured geoforms", including moraines and meltwater plains on silty or clayey till, and "Pleistocene coarse-textured geoforms", which were meltwater plains or marine terraces of loose sediment of sand and gravel. Holocenic landscapes were alluvial or lacustrine deposits and were denominated "Valleys" and "Lakes", respectively.
Mixed landscapes, which covered a considerable area on the ranch, had Tertiary morphology (asymmetrical hills) but with a thin glacial covering. They were classified in 2 groups according to relief: "Mixed low hills" and "Mixed high hills".

\section{Vegetation and Its Environment: Classification of Plant Communities}

Successive divisions of the TWINSPAN are shown in Fig. 2 together with the indicator species. Six groups of samples or community types were obtained from the analysis. Presence and/or abundance of the group of species considered indicators of acid conditions, i.e. dwarf-shrubs such as Empetrum rubrum, Bolax gummifera ((Lam.) Sprengel), Azorella lycopodioides (Gaudich.), Baccharis magellanica ((Lam.) Pers.), Pernettya pumila ((L. f.) Hooker), and Berberis empetrifolia (Lam.), warranted grouping of these 6 types into the 2 following large ecological divisions: neutrophilous and acidophilous (Collantes et al. 1989).

\section{Neutrophilous Types}

1- Poa short-grassland: An anthropogenic community of short grasses and sedges dominated by Poa rigidifolia complex (Giussani et al. 1996) and Carex andina (Phil.).

2- Festuca-Poa grassland: Tussock grassland lacking acidity indicators dominated by a dense cover of Festuca gracillima with an abundance of $P$ oa rigidifolia complex and many forbs.

3- Chiliotrichum dense scrub: A three-layered scrub with a dense cover of Chiliotrichum diffusum frequently forming a closed canopy together with Berberis buxifolia (Lam.) and eventually Ribes magellanicum (Poiret.) It has some characteristic species such as Galium aparine (L.) and Osmorhiza chilensis (Hooker \& Am.).

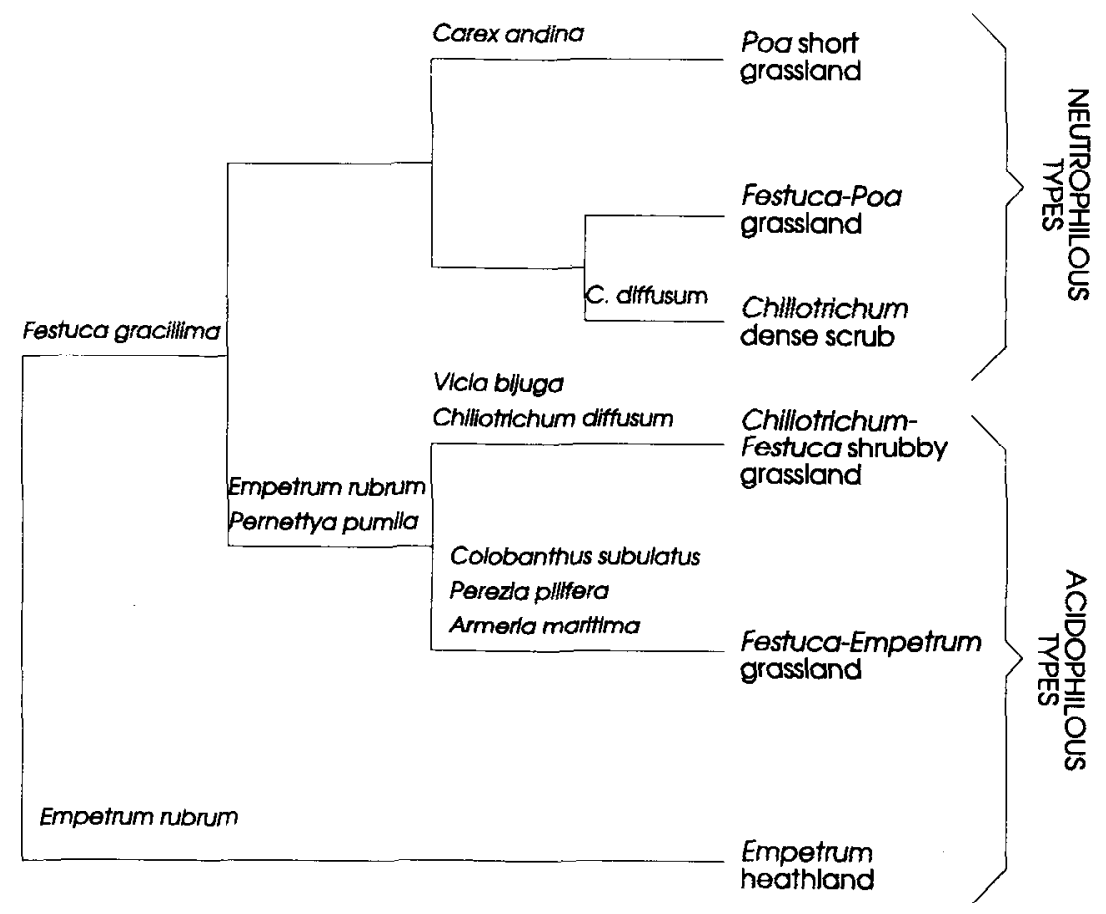

Fig. 2. Dendogram which represents the successive group divisions of the 64 samples with the TWINSPAN classification method. For each division, indicator species are shown. The $1^{\text {st }}$ division separates Empetrum heathland from the other community types. Next division separates neutrophilous types from the reminder acidophilous types. After 2 more division levels, 3 neutrophilous community types, and 2 acidophilous community types were finally obtained. 


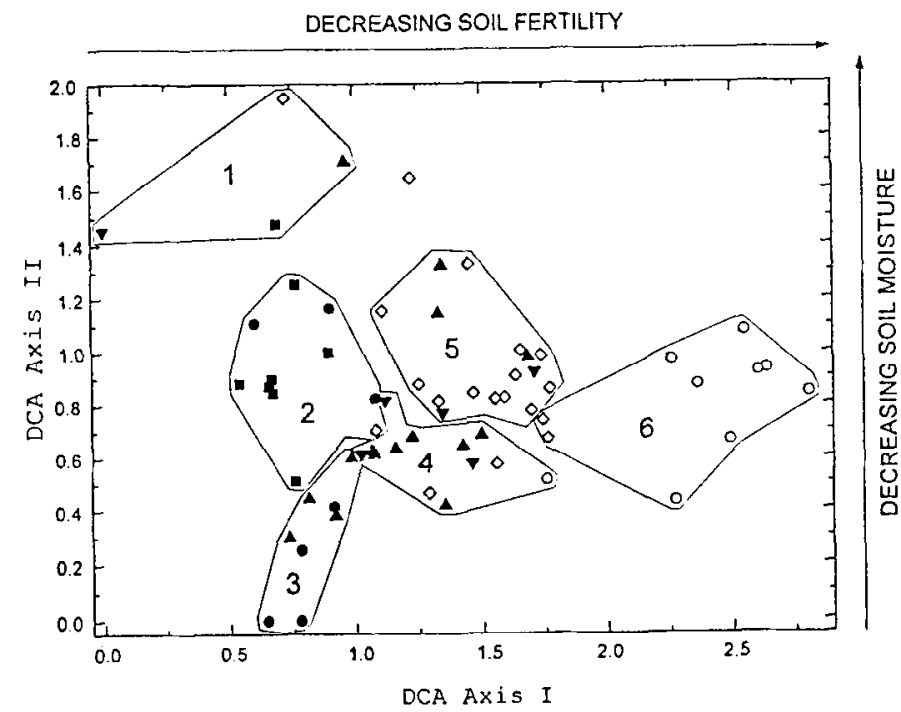

Fìg. 3. Floristic ordination diagram (DCA) for first (I) and second (II) axes. Symbols represent landscape types. Tertiary undulated plains, - Tertiary hills, $\Delta$ Mixed low hills, $\nabla$ Mixed high hills, - Pleistocene mid-textured geoforms, O Pleistocene coarse-textured geoforms. Lines enclose community types classified by TWINSPAN; 1- Poa short grassland, 2- Festuca-Poa grassland, 3Chiliotrichum dense shrub, 4- Chiliotrichum-Festuca shrubby grassland, 5- Festuca-Empetrum grassland, 6- Empetrum heathland.

\section{Acidophilous Types}

4- Chiliotrichum-Festuca shrubby grassland: Tussock grassland with a sparse to fairly close layer of the shrub Chiliotrichum diffusum. Subdominant species are the dwarf-shrubs Empetrum rubrum and Baccharis magellanica.

5- Festuca-Empetrum grassland: Tussock-grassland of Festuca gracillima with variable presence of Chiliotrichum diffusum and acidophilous dwarf shrubs and forbs such as Geum magellanicum (Comm. ex Pers.), Primula magellanica (Lhem.), Gentianella magellanica ((Gaudich.) Fabris ex D. M. Moore), and Perezia pilifera ((D. Don) Hooker \& Arn.).

6- Empetrum heathland: A cushion heathland dominated by Empetrum rubrum together with characteristic cushion and dwarf shrubs. Grasses were scarce with most common species being Deschampsia flexuosa ((L.) Trin.) and Trisetum spicatum ((L.) K. Richter). Vegetation cover was variable and wind and water erosion common.

\section{Vegetation and Its Environment: Ordination of Plant Communities}

Figure 3 shows the display of vegetation samples on the 2 first ordination axes. The eigenvalues, indicators of the annount of community variation explained, were 0.49 and 0.29 for Axes I and II respectively. The ordination placed neutrophilous community types in the negative side and acidophilous types at the positive side of Axis I. The order occupied by each community type in this axis, and the species scores (not shown in the diagram), were similar to those found in the regional studies (Collantes et al. 1989, Collantes et al. unpublished), in which fertility parameters were measured. Thus, we concluded that Axis I represented a fertility gradient described by the presence and abundance of acidophilous dwarf-shrubs.

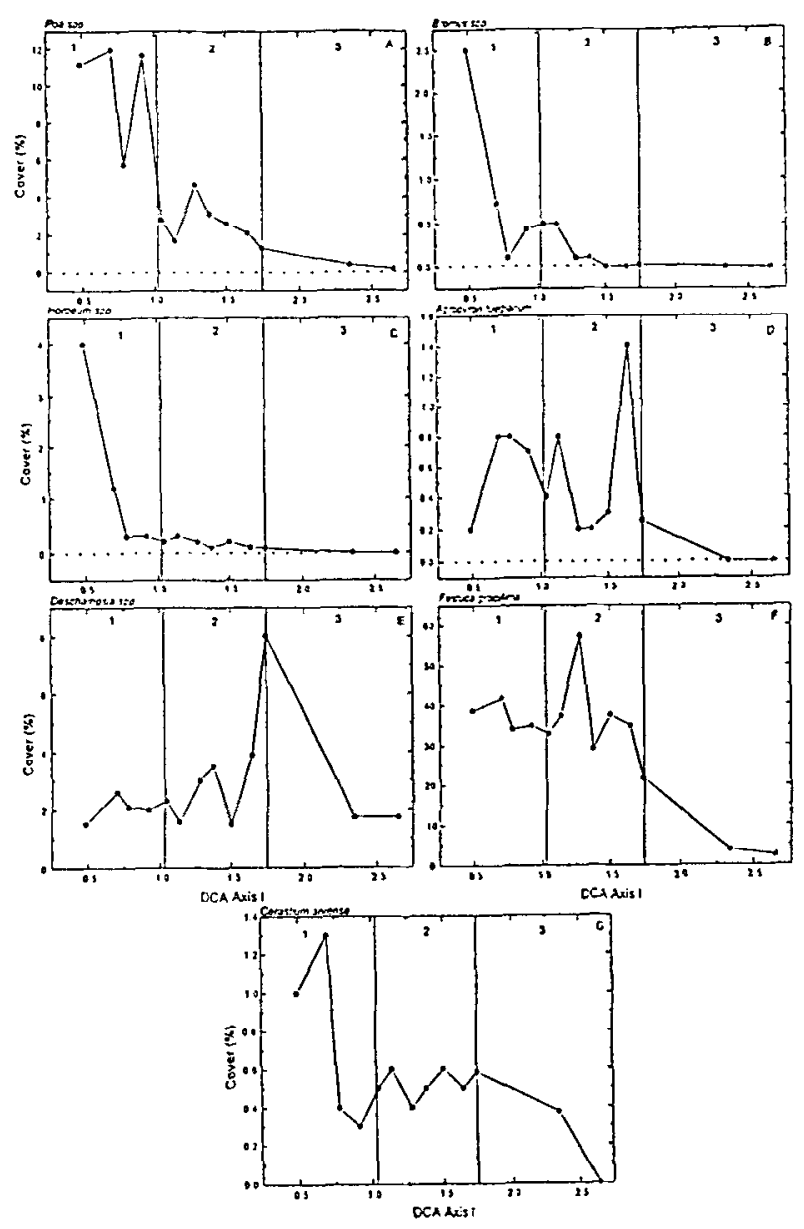

Fig. 4. Cover values of selected forage species along Axis I. Three areas were delimited 1- Neutrophilous grasslands and shrublands; 2- Acidophilous grasslands and shrublands; 3-Empetrum heathland. The curves were smoothed by averaging the scores in groups of 5.

Axis II separated grasslands from shrublands and represented a moisture gradient. At the top of the diagram, the Poa short grassland was typical of xeric soils and $\mathrm{N}$-facing slopes; while at the bottom, the Chiliotrichum diffusum dense scrub was common on S-facing slopes and wetlands borders and increased its presence towards the south with increasing precipitation (Collantes et al 1989, Collantes et al. unpublished).

The relationship between landscape types and plant communities was graphically depicted in Fig. 3. In Tertiary landscapes, only neutrophilous types were found; whereas Pleistocene land forms had Empetrum heathlands and acidophilous grasslands. Mixed landscapes had types of both ecological groups. In the eutrophic extreme, the Poa short grassland, being a topographic disturbed community, was not related to any landscape type. The figure also showed that grasslands and heathlands occurred mostly in plains, whereas shrubby vegetation did so in hilly country.

\section{Vegetation Map}

Due to printing costs the original vegetation map scale $1: 40,000$ (a $150 \times 100 \mathrm{~cm}$ sheet) was not presented here. Instead, 
Table 2. Spearman rank correlation coefficients between first and second axes of DCA and species cover.

\begin{tabular}{lll}
\hline & Axis I & Axis II \\
\hline Agropyron fuegianum & $-0.19 \mathrm{NS}$ & $-0.27^{*}$ \\
Bromus spp. & $-0.57^{*}$ & $0.20 \mathrm{NS}$ \\
Cerastium arvense & $-0.24^{*}$ & $-0.20 \mathrm{NS}$ \\
Deschampsia spp. & $-0.05 \mathrm{NS}$ & $-0.11 \mathrm{NS}$ \\
Festuca gracillima & $-0.41^{*}$ & $-0.09 \mathrm{NS}$ \\
Hordeum spp. & $-0.45^{*}$ & $-0.05 \mathrm{NS}$ \\
Poa spp. & $-0.71^{*}$ & $-0.06 \mathrm{NS}$ \\
\hline
\end{tabular}

NS, not significant; *, $\mathrm{P}<0.05$

the distribution of community types in the different landscape types of Fig. 1 are shown in Table 1. Besides the 6 upland community types classified by TWINSPAN, the 2 main types of lowlands (meadows and halophytic marshes), separated by photo interpretation and shown in the vegetation map, are given in Table 1. The distribution of community types on landscapes of the ranch (Table 1) reflected, and in some cases reinforced, the vegetation/landscape relationships shown in Fig. 3. In most cases, 1 or 2 community types dominated each landscape.

\section{Forage Gradients}

Five (Festuca gracillima, Poa spp., Hordeum spp., Bromus spp., and Cerastium arvense) out of the 7 forage taxa selected had a significant $(P<0.05)$ correlation with Axis I (Table 2). In each case, the correlation was negative indicating higher cover values towards the neutrophilous end point. In Fig. 4, percentage cover of the 7 taxa was plotted against Axis I. Poa spp., had the highest correlation with Axis I and also the highest cover values after the dominant tussock grass $F$. gracillima. Deschampsia spp., which also had relatively high cover, was not correlated with Axis I, and had its highest abundance in the mid-acidophilous sector of the gradient (Fig. 4 E).
Table 3. Estimated values and confidence intervals (95\%) of annual mean production indices for the 6 landscape types ${ }^{1}$ and calculated lamb production ${ }^{2}$.

\begin{tabular}{cccccc}
\hline \hline & $\begin{array}{c}\text { Axis I } \\
\text { score }\end{array}$ & marking & mortality & $\begin{array}{c}\text { stocking } \\
\text { rate }\end{array}$ & $\begin{array}{c}\text { lamb } \\
\text { production }\end{array}$ \\
\hline & & $(\%)$ & $(\%)$ & $(\mathrm{EE} / \mathrm{ha})$ & (lambs/ha) $^{2}$ \\
$\mathrm{~A}^{1}$ & 0.812 & $83.04 \pm 7.18$ & $6.04 \pm 2.27$ & $1.11 \pm 0.15$ & 0.86 \\
$\mathrm{~B}$ & 0.933 & $79.90 \pm 5.78$ & $6.95 \pm 1.83$ & $1.06 \pm 0.12$ & 0.79 \\
$\mathrm{C}$ & 1.228 & $72.27 \pm 3.96$ & $9.16 \pm 1.25$ & $0.95 \pm 0.08$ & 0.62 \\
$\mathrm{D}$ & 1.313 & $70.07 \pm 4.18$ & $9.80 \pm 1.32$ & $0.92 \pm 0.08$ & 0.58 \\
$\mathrm{E}$ & 1.468 & $66.05 \pm 5.35$ & $10.97 \pm 1.70$ & $0.86 \pm 0.08$ & 0.51 \\
$\mathrm{~F}$ & 2.143 & $48.58 \pm 14.06$ & $16.03 \pm 4.46$ & $0.61 \pm 0.19$ & 0.25 \\
\hline
\end{tabular}

${ }^{1}$ Landscape types: A, Tertiary undulated plains; B, Tertiary hills; C, Mixed low hills; D, Mixed high hills; E, Pleistocene mid-textured geoforms; F, Pleistocene coarse-textured geoforms.

${ }^{2}$ Number of lambs per ha $=$ (stocking rate - stocking rate $X$ mortality percentage $\left./ 100\right)$ $X$ marking percentage/ 100 .

\section{Vegetation/Sheep Production Relationships}

In Fig. 5, the centroids of the community types were plotted against both ordination axes, and paddocks and landscape types were positioned according to their composition of community types. Most paddocks clustered around 1 or 2 landscape types which indicated that puddocks were good examples of the floristic composition of different landscape types. Paddocks on Tertiary landscapes A and B were dominated by the Festuca-Poa community type. Paddocks on mixed landscapes $C$ and D were at the center of the fertility gradient, and mainly covered by the shrubby grassland and the Festuca-Empetrum grassland. Paddocks on Pleistocene landscapes E and F had extremely acidophilous composition and graded from lands dominated by the Festuca-Empetrum grassland to paddocks almost totally covered by the Empetrum heathland.

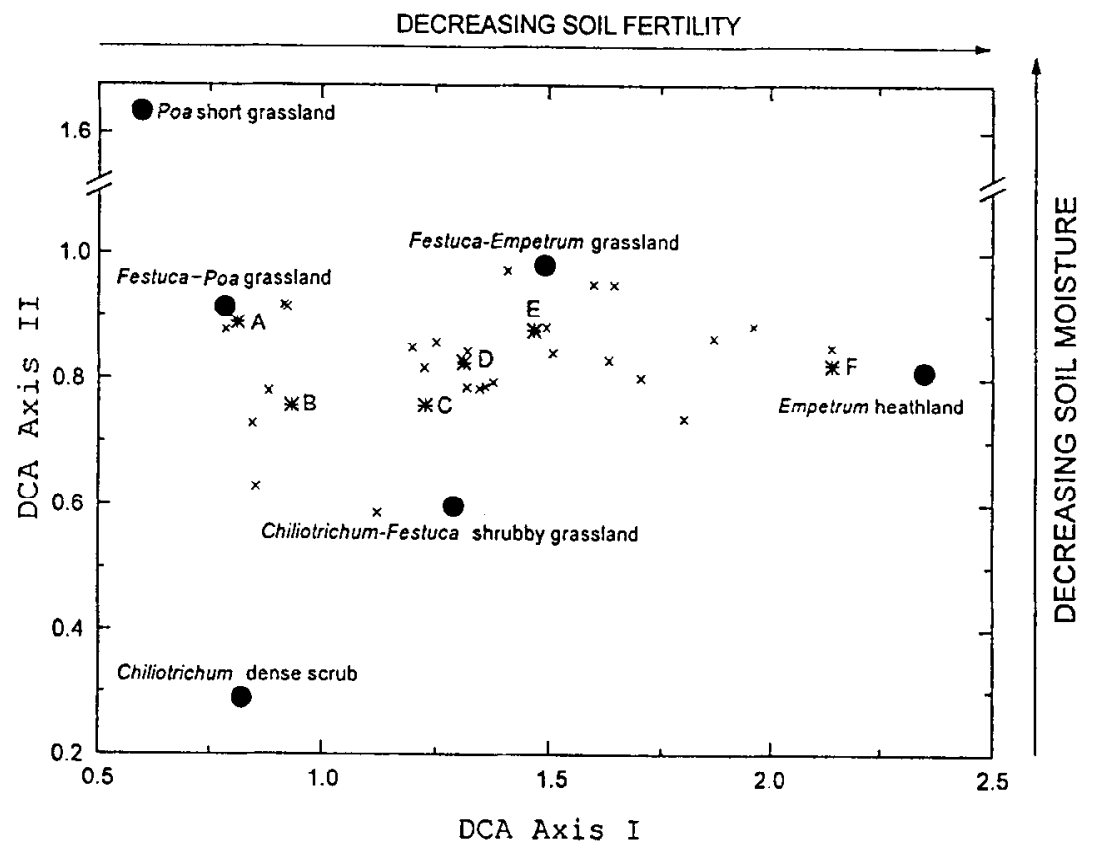

Fig. 5. Location of the centroids of the community types $\left({ }^{\bullet}\right)$ for the first and second axes of DCA. Paddocks $(X)$ and types of landscape $(*)$ were located according to their proportion of community types as explained in text. A, Tertiary undulated plains; B, Tertiary hills; C, Mixed low hills; D, Mixed high hills; E, Pleistocene mid-textured geoforms; F, Pleistocene coarse-textured geoforms. 

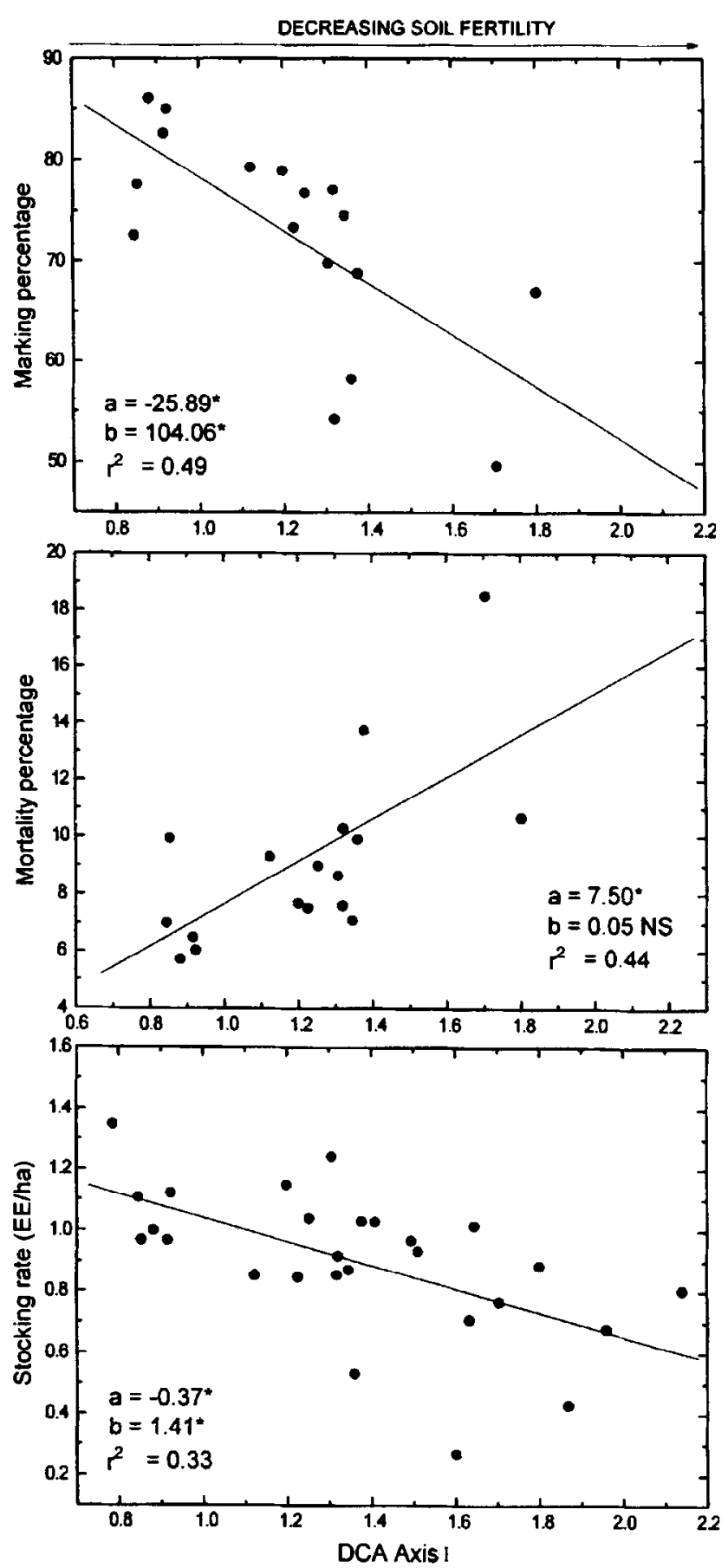

Fig. 6. Linear regressions of paddock mean production indexes (marking percentage, mortality, and stocking rate) on ordination Axis I of DCA. a = slope; $b=$ intercept; * $\mathbf{P}<0.05$; NS, not significant.

The regression analyses between paddock scores and paddock productivity indices are shown in Fig. 6. Axis I had a significant correlation with all 3 indices with lamb marking percentage having the highest $r^{2}$. The 3 regression analyses indicated that paddocks with the lowest scores on Axis I were the best production lands. Correlations of the productivity indices with Axis II were not significant.
Mean productivity indices for each landscape type were estimated from the linear functions according to their position on Axis I (see Fig. 5) and are presented in Table 3. Tertiary landscapes, covered by neutrophilous communities, were the best sheep breeding lands, especially the Tertiary plains which had an estimated marking percentage significatively higher than any Pleistocene or Mixed landscape. The Mixed landscapes were in an intermediate position. Pleistocene landscapes, dominated by acidophilous types, were the worst sheep breeding lands. Of them, the coarse-textured geoforms, of extensive Empetrum heathlands, had the poorest productivity indices. In the last column of Table 3 the average lamb production (number of lambs $\mathrm{ha}^{-1} \mathrm{yr}^{-1}$ ), calculated from the 3 indices, emphasizes the differences between landscapes.

Results from the regression analysis of the production indices on the percentage of meadows and marshes in the paddocks showed that for stocking rate there was a significant, but low correlation $\left(r^{2}=0.17\right)$. There was no significant relationship for marking percentage and mortality.

\section{Discussion}

This study, intended to detect landscape patterns of animal productivity for the Fuegian steppes, showed that the regional fertility gradient of floristic variants of the steppe is, in several ways, a forage gradient related to animal performance.

Answering our first question, results of classification and ordination showed that in the María Behety ranch the main regional vegetation types were present and covered the fertility and moisture gradients detected for the whole area (Collantes et al. 1989 , Collantes et al. unpublished). The vegetation response to fertility would relate to rock texture and mineral composition. Tertiary rocks are of finer texture and richer in bases than Quaternary deposits, which have large proportions of quartzose sand (Codignotto and Malumian 1981). The Mixed parent material usually presented a patchy pattern of habitats differing in fertility. Although acidophilous variants dominated (Fig. 3, Table 1) they were of a more intermediate nature, as the thin layer of acidic material would not preclude the influence of the deeper sediment on soil properties (Anchorena et al. 1991).

In relation to the second question, most forage species preferred by sheep had a positive association with the fertility gradient (Fig. 4, Table 2) while only one was correlated with the moisture gradient (Table 2). The response of most grass species to the fertility gradient was in accord with the ecology of grasses and with composition of oceanic grasslands in relation to soil fertility (Grime et al. 1988, Perkins 1978, King and Nicholson 1964). Soils with base saturation lower than $50 \%$ and pH lower than 5.8 , as in the Empetrum heathland (Collantes et al. 1989), have enough interchangcablc aluminum to affect plant growth (Kamprath 1967). Most grasses and herbs prefer base-rich soils (Perkins 1978, Pearsall 1965) such as the soils of the FestucaPoa grasslands and the Chiliotrichum dense scrub with $75-90 \%$ base saturation and $\mathrm{pH}$ values of 6-6.7 (Collantes et al. unpublished). The Festuca-Poa grassland has special significance for its high cover of grasses, mainly $P o a$, the principal item in sheep diet (Posse et al. 1996), together with its large area (Table 1). In boreal oceanic grasslands, Poa species attain dominance in baserich soils (King and Nicholson 1964). Deschampsia spp is the 
exception to the general behavior of grasses. Its principal species is $D$. flexuosa, a known acidophilous grass in boreal grasslands (Grime et al. 1988, Douchaufour 1987).

The 3 indices of animal productivity were associated with the fertility gradient (Fig. 6) but not with the moisture gradient. These results answered our third question: the best breeding performance was strongly associated with the neutrophilous end point of the fertility gradient, i.e. to paddocks situated in Tertiary landscapes. Biologically and economically the most important fact was the increase in lambing related to Tertiary lands. Stocking rate, survival, and prolifacy accounted together for a $37 \%$ average increase in lamb production (number of lambs $\mathrm{ha}^{-1}$ $\mathrm{yr}^{-1}$ ) in Tertiary landscapes compared to Mixed landscapes, and $116 \%$ compared to Pleistocene landscapes (Table 3 ).

Detection of a forage gradient across landscape types suggested nutritional causes for the sheep production differences. The most important feeding factors related to sheep reproductive performance are ewe nutritional status at mating (Coop 1962) and at late pregnancy (Wilkinson and Chestnutt 1988). The effect of good nutrition prior to mating has been expressed mainly in multiple births, and especially in Corriedale ewes (Coop 1962). As an indication of this effect, the first 5 paddocks of the neutrophilous endpoint (Fig. 6) encompassed the 9 cases in which markings were higher than $100 \%$ along the 30 year period. Nutritional status at mating should reflect summer grazing which occurs mostly on the lowlands (Anchorena and Collantes 1989). However, no correlation was found between percentage of meadows and marshes in paddocks and lamb marking. Because our performance data were integrated measures of sheep production cycles, it was difficult to ascertain the nature of this lack of correlation. It could be that the range in proportion of lowlands ( 12 to $30 \%$ ) was large enough as not to be restrictive of liveweight at mating, or that their effect was masked by a later and stronger effect of upland vegetation. Also, the eventual effect of larger area of lowlands on liveweight at mating could be counterbalanced by the decrease of the actual grazing area due to lack of access to lowlands in winter.

Differences in sheep production between landscapes were consistent with differences in cover of most forage taxa. However, in Mixed landscapes, the relatively low cover of Poa and other forage grasses should be partially compensated by the increase of Deschampsia spp., which was the second item in sheep diet (Posse et al. 1996). The magnitude of the difference in lamb production favorable to Tertiary landscapes suggested that Poa species, their principal forage, have a strategic value for breeding due to the opportunity of nutritional offer in relation to ewe requirements. Iglesias et al. (1992) found, for the southern continental area including the Magellanic steppe, that ewe liveweight in late pregnancy was more important than weight at mating with regard to lamb marking percentage. Relevance of ewe nutrition in late pregnancy has been stressed by Wilkinson and Chestnutt (1988), who related it to lamb birthweight; by Alexander (1956) and Maund et al. (1980), who related lamb birthweight to survival; and by Russell (1982) and Maari (1987), who related it to lactation performance. In our area, feeding during late pregnancy (winter and early spring) seems to depend largely on Poa species which are the earliest perennial grasses in Patagonia (Nicora 1978). Phenology of Poa species precedes that of Deschampsia flexuosa by about 1 month (Grime et al. 1988) and may possibly be the cause of the sharp increase of Poa in spring diets (Posse et al. 1996).
Other causes of the notable decrease of production at the center of the fertility gradient may be adscribed to shrub encroachment. While paddocks in Tertiary landscapes were dominated by the Festuca-Poa grassland, a community without shrubs, paddocks on Mixed landscapes, at the center of the gradient, were dominated by acidophilous communities with high to medium cover of Chiliotrichum (Table 1) which causes problems with access to forage. Shrub cncroachment would also be responsible in part for the lack of effect of moisture increase, related to shrub increase, on production.

Sheep productivity had a close relationship with parent rock material in a Boreal atlantic area such as Wales (Hughes 1978 , Brasher and Perkins 1978). Although the Magellanic steppe has much lower rainfall, comparable results seem to indicate the relevance of parent material composition in oceanic cold-temperate climates, where soil acidification is the prevalent soil process, to determine economical output of landscapes.

\section{Conclusions}

Animal production-vegetation relationships found in this work reveal biological responses at a broad scale not always considered in land management. Extensive lithological mantles imposed particular community patterns and the actual nutritional value of landscapes. Results of this study could be applied to establish market or tax values of land, as well as for management purposes. Lands usually assigned to breeding ewes can differ notably in their economical production. Tertiary landscapes, that generally cover smaller areas, should be reserved for special breeding operations such as first service ewes or selection flocks. The proportion of lowlands should not be taken into account for assigning winter stocking rates. Lack of influence of lowlands percentage on production indicated that continuous grazing with rigid stocking rates impaired the effects of summer use of meadows and marshes and suggested that a seasonal grazing system would be preferable. In many breeding paddocks the apparent tendency of shrubs to decrease sheep performance by limiting access to forage suggests the separation of grasslands from shrubby communities to force the use of the latter. In general, grazing management and rest-rotation planning should be designed to favor the growth and to ensure the permanence of Poa species which appeared as the key forage for lambing in these lands.

\section{Literature Cited}

Alexander, G. 1956. Influence of nutrition upon duration of gestation in sheep. Nature (London). 178:1058-1060.

Anchorena, J. and M.B. Collantes. 1989. Utilización del paisaje por ovinos en Tierra del Fuego. p. 165. In Resúmenes de la XIV Reunión Argentina de Ecología. Asociación Argentina de Ecología, S.S de Jujuy.

Anchorena, J., O. Bianciotto, and M.B. Collantes. 1991. Los suelos del norte de Tierra del Fuego. p. 193-195. In Actas del XIII Congreso Argentino de la Ciencia del Suelo. San Carlos de Bariloche.

Belza, J.E. 1975. En la isla del fuego. 2. Colonización. Publicación del Instituto de Investigaciones Históricas Tierra del Fuego. Buenos Aires.

Brasher, S. and D.F. Perkins. 1978. The grazing intensity and productivity of sheep in the grassland ecosystem. p. 354-374. In: O.W. Heal and D.F. Perkins (eds.). Production ecology of British moors and montane grasslands. Springer-Verlag, Berlin, Heidelberg, New York. 
Buffoni, H. and C. Paz. 1982. El conocimiento de los requerimientos nutricionales del ganado y su utilidad en el ajuste de la carga animal. Extension Bull. INTA, Río Gallegos.

Cabrera, A.L. 1971. Fitogeografía de la República Argentina. Bol. Soc. Arg. Bot. 14:1-42.

Codignotto, J.O. and N. Malumian. 1981. Geología de la Región al Norte del Paralelo 54 $\mathrm{S}$ de la Isla grande de la Tierra del Fuego. Rev. Asoc. Geol. Arg. 36:44-88.

Collantes, M.B., J. Anchorena, and G. Koremblit. 1989. A soil nutrient gradient in Magellanic Empetrum heathlands. Vegetatio 80:183-193.

Conover, W.J. 1980. Practical Nonparametric Statistics. John Wiley and Sons, New York.

Coop, I.E. 1962. Liveweight productivity relationships in sheep. Liveweight and reproduction. New Zeland J. Agr. Res. 5:249-264.

Correa, M.N. 1969-1984. Flora Patagónica. Col. científica del INTA, Buenos Aires. Vol. VIII

Duchaufour, Ph. 1987. Manual de Edafología. Masson, Barcelona.

Frederiksen, P. 1988. Soils of Tierra del Fuego. A satellite-based land survey approach. Folia Geographica Danica 18:1-159.

Fuerza Aérea Argentina. 1986. Estadísticas meteorológicas. Buenos Aires.

Giussani, L.M., A.J. Martinex, and M.B. Collantes. 1996. Morphological variation associated with the environment in four dioecious Patagonian Poa species: the Poa rigidifolia complex. Can. J. Bot. 74:762.

Grime, J.P., J.G. Hodgson, and R. Hunt. 1988. Comparative plant ecology. Unwin Hyman, London.

Hill, M.O. 1979. TWINSPAN. A Fortran program for arranging multivariate data in an ordered two-way table by classification of the individuals and attributes. Section of Ecology and Systematics, Cornell University, Ithaca, N.Y.

Hill, M.O. and H.G. Gauch, Jr. 1980. Detrended correspondence analysis: An improved ordination technique. Vegetatio 42:47-58.

Hueck, K. and P. Seibert. 1972. Vegetationskarte Von Südamerika. Stuttgart.

Hughes, R.E. 1978. Studies in sheep population and environment in the mountain of Northwest Wales. J. Appl. Ecol. 10:107-112.

Iglesias, R., B. Alegre, D. Barría, J. Larrosa, and H. Tapia. 1992. Factores que inciden en la eficiencia reproductiva ovina. I. Peso corporal. p. 138-157. In Actas del III Congreso Mundial de Ovinos. Buenos Aires.

Instituto Geográfico Militar. 1942. Hoja 5369. In Carta topográfica de la República Argentina. Buenos Aires.

Kamprath, F.J. 1967. Soil acidity and response to liming. Internal Soil Testing Series. Soil Science Department, North Carolina, State University, Raleigh, North Carolina. Tech. Bull. 4.

King, J. and I.A. Nicholson. 1964. Grasslands of the forest and subalpine zones. p. 168-215. In: J.H. Burnett (ed.). The Vegetation of Scotland. Oliver and Boyd, Edinburgh.

Koremblit, G. and J. A. Forte-Lay. 1991. Contribución al estudio agroclimático del Norte de Tierra del Fuego (Argentina). Ans. Ins. Pat. Ser. Cs. Nats. 20:125-133.

Maari, J.J. 1987. Enfermedades que afectan la supervivencia del cordero. p. 73-100. In: J. Bonino Morlán, A. Durán del Campo, and J.J. Maari (eds.). Enfermedades de los lanares. Editorial Hemisferio Sur, Buenos Aires.

Maund, B.A., S.J. Duffell, and C.E. Winkler. 1980. Lamb mortality in relation to prolificacy. Expl. Husb. 36: 99-112.

Mc.Naughton, S.J. 1985. Ecology of a grazing ecosystem: the Serengeti. Ecol. Monographs. 55:259-294.

Mc.Naughton, S.J., R.W. Reuss, and S. W. Seagle. 1988. Large mammals and process dynamics in African ecosystems. BioSci. 38:794-800.

Moore, D.M. 1983. Flora of Tierra del Fuego. Anthony Nelson, London.

Nicora, E.G. 1978. Gramineae. Parte III. In: M.N. Correa (ed.). Flora Patagónica. Col. Científica del INTA, Buenos Aires. Vol VIII.

Pearsall, W.H. 1965. Mountains and moorlands. 3th edition. Collins St. Jame's place, London.
Pearson, S.M., M.G. Turner, L.L. Wallace, and W.H. Romme. 1995. Winter habitat use by large ungulates following fire in northern Yellowstone National Park. Ecological Appl. 5(3):744-755.

Perkins, D.F. 1978. Snowdonia grassland: introduction, vegetation and climate. p. 289-296. In O.W. Heal and D.F. Perkins (eds.). Production ecology of British moors and montane grasslands. Springer-Verlag, Berlin, Heidelberg, New York.

Posse, G., J. Anchorena, and M.B. Collantes. 1996. Seasonal diets of sheep in the steppe region of Tierra del Fuego, Argentina. J. Range Manage. 49:24-30.

Russell, A.J.F. 1982. Nutrición de las ovejas gestantes. p. 157-163. In Manejo y enfermedades de las ovejas. Editorial ACRIBIA, Buenos Aires.

Senft, R.L., M.B. Coughenour, D.W. Bailey, L.R. Rittenhouse, O.E. Sala, and D.M. Swift. 1987. Large herbivore foraging and ecological hierarchies. BioSci. 37:789-799.

Turner, M.G., V.H. Dale, and R.H. Gardner. 1989. Predicting across scales: theory development and testing. Landscape Ecol. 3:245-252.

van der Maarel, E. 1979. Transformation of cover-abundance values in phytosociology and its effects on community similarity. Vegetatio 39:97-114

Walter, H. and E.O. Box. 1983. Climate of Patagonia. p. 432-435. In: N.E. West (ed.). Temperate deserts and semi-deserts. Elsevier Scientific Publishing Company, Amsterdam.

Westhoff, V. and E. van der Maarel. 1978. The Braun-Blanquet approach. p. 287-399. In: Whittaker, R.H. (ed.). Classification of plant communities. Junk, The Hague.

Wilkinson, S.C. and D.M.B. Chestnutt. 1988. Effect of level food intake in mid and late pregnancy on the performance of breeding ewes. Anim. Prod. 47:411-419. 